sober notenapparaat is toegevoegd met eindnoten na elke brief (de gekozen letter had van mij wel wat groter gemogen). Het register bevat alleen persoonsnamen, geen plaatsnamen en geen zaken. Het geheel wordt verlucht met enige foto's van het handschrift, historische afbeeldingen en contemporaine kiekjes van de diverse woonplaatsen van de Fijnjes in Nederland en Frankrijk. Van Emilie zelf is geen portret, tekening of silhouet bekend.

De inleiding geeft zoals gebruikelijk een achtergrondschets van de hoofdpersoon, haar familieachtergrond, de politieke ontwikkelingen en een verantwoording van de uitgave. De inleiding is mijns inziens te lang, 81 bladzijden inleiding en 200 bladzijden brieven. Dit komt omdat de bewerker op de bladzijden 34-77 een beeld van de belevenissen van Emilie in ballingschap uit haar brieven schetst, zeer leesbaar weliswaar en de moeite waard om te lezen, maar mij dunkt overbodig, omdat het zo dubbelop gaat. Een klein minpunt derhalve; de overheersende indruk is evenwel zeer positief en ik kan dit egodocument de lezer van harte aanbevelen.

H. Boels

\title{
NIEUWSTE GESCHIEDENIS
}

M. C. A. Kessels-van der Heijde, Maastricht, Maestricht, Mestreech. De taalverhoudingen tussen Nederlands, Frans en Maastrichts in de negentiende eeuw (Dissertatie Nijmegen 2002, Maaslandse Monografieën LXV; Hilversum: Verloren, 2002, 315 blz., ISBN 906550713 2).

Taalkundigen en geschiedschrijvers spraken er in het midden van de negentiende eeuw al hun verwondering over uit: Maastricht was een drietalige stad. De officiële stukken werden in het Nederlands gesteld, de bovenlaag van de samenleving sprak en schreef Frans, maar in het alledaags spraakgebruik en bij informele contacten bediende men zich van het dialect. Al deden zich ook verschuivingen voor, de triglossie bleef heel de lange negentiende eeuw door, van 1780-1914, in stand. Het was een fenomeen dat in Nederland verder nergens werd aangetroffen.

Tot heden ontbrak een sociolinguïstische studie van dit fenomeen. Mevrouw Kessels besloot het hiaat te vullen, maar stuitte meteen op moeilijkheden. Het taalgebruik in het negentiendeeeuwse Maastricht is zeer verschillend gedocumenteerd. Zo rijk als de bronnen vloeien over het gebruik van het Frans, zo schamel is de informatie over het dialectgebruik. Daar komt bij dat de linguïstische theoretici diepgaand van mening verschillen over de achtergronden van meertaligheid. Sommigen zoeken het in sociale tegenstellingen: de maatschappelijke bovenlaag bedient zich van een cultuurtaal met internationale allure, een middengroep geeft om economische redenen de voorkeur aan de landstaal en het gewone volk beperkt zich tot het dialect. Anderen houden het erop dat elk der talen zijn eigen domein heeft. Publieke functionarissen leggen een andere voorkeur aan de dag dan personen actief in de culturele en de journalistieke wereld. Hun keuzes kunnen weer afwijken van de gewoonten op de werkvloer en in het informele circuit.

Een eerste verkenning van het bronnenmateriaal maakte al duidelijk dat men in het negentiende-eeuwse Maastricht misschien wel sociale lagen zou kunnen identificeren met een voorkeur voor Frans of dialect, maar zeker niet een die men als Nederlandstalig kon betitelen. Het leek er veeleer op dat de taalvoorschriften die sinds 1823 golden voor het openbaar bestuur en het notariaat de beslissende stoot gaven voor gebruik van het Nederlands. De auteur besloot daarom de domeinhypothese te toetsen. 
In heuristisch opzicht was het zeker een gelukkige keuze. Systematisch onderzoek naar de taal gebezigd in de gemeenteraad, de brieven van de burgemeesters, de notariële akten, kranten, advertenties, in Maastricht gedrukte boekwerken en in de archieven van scholen en families leverde een schat aan informatie op over de voorkeur voor een van de drie talen. In de eerste jaren van de negentiende eeuw won het Frans sterk veld. Maastricht was van 1796 tot 1814 hoofdstad van een tot Frankrijk behorend departement. Onderwijsinstellingen en overheid waren verplicht zich in het Frans uit te drukken. De bovenlaag van de samenleving had er geen moeite mee. Ze omarmde het Frans gretig als cultuurtaal. Het theater bracht Frans repertoire, op de soirées vertolkte jeugdig talent aria's uit Franse opera's. Het zou tot 1850 zo blijven. De taalwetten van 1823 vermochten zelfs de burgemeesters en de notarissen niet te verleiden hun pennenvruchten steeds in het Nederlands te stellen. De plaatselijke kranten bleven zelfs tot ruim na het midden van de eeuw overwegend Franstalig. De boekdrukkers wisselden wat sneller van voorkeur. Was van 1794 tot 1814 60\% Frans- en $40 \%$ Nederlandstalig, tussen 1816 en 1839 was het omgekeerd.

De auteur meent dat de vertraging in de verschuiving naar het Nederlands, die door de koning met zoveel nadruk werd bevorderd, vooral te wijten was aan de economische relaties van de stad, die meeliftte met het snel industrialiserend Franstalige Luik. In de ontwikkeling van enkele inheemse grote bedrijven in de sectoren glas, aardewerk en papier in de tweede helft van de negentiende eeuw ziet ze vervolgens de grond voor de toename van het Nederlands, dat gaandeweg ook de pers en het theater in zijn greep kreeg. Van 1875 af bevorderden plaatselijke taal- en letterkundigen die trend.

De auteur meent dat deze ontwikkelingen passen in haar domeinhypothese. Het brengt haar evenwel in problemen. Ze moet toegeven dat tussen 1875 en 1914 juist de gewone man behoefte bleek te hebben aan kennis van de Franse taal. Op de laagste niveaus van het voortgezet onderwijs - de zevende en achtste klas van de lagere school en de voor boeren, ambachtslieden en kleine middenstanders bestemde burgeravondschool - werd in Maastricht meer aandacht besteed aan het Frans dan waar ook in Nederland. Tegelijk begon het dialect triomfen te vieren. De sociëteit Momus speelde de voortrekkersrol. Ze verenigde leden van de hogere burgerij met filantropische aspiraties en een dringende behoefte de lokale feestcultuur op een hoger plan te brengen door het volk te leren op een nette manier carnaval te vieren.

Het lukt niet goed dit onder te brengen in het gekozen verklaringsmodel, waarschijnlijk omdat is verzuimd kennis te nemen van de literatuur over het taalgebruik in een andere regio met drietaligheid - ditmaal Frans, Duits en een regionaal dialect - , de Elzas. In de eerste fase van de industrialisatie, vanaf 1840, werd daar rond de agglomeratie Straatsburg een stedelijk netwerk gevormd met uitstraling naar beide zijden van de Rijn. Er ontstond een geïntegreerde arbeidsmarkt, die de steden en dorpen aan de oostzijde van de Elzas en het aan de andere zijde van de rivier gelegen deel van Baden-Württenberg tot een perfecte economische eenheid samensmeedde. Arbeiders die nu eens aan deze, dan weer aan gene zijde van de Frans-Duitse grens werkten hadden minstens een rudimentaire kennis van beide talen nodig. Maar gewoonlijk bleef er enige taalachterstand die dwong bij informele contacten de voorkeur te geven aan het dialect.

Iets soortgelijks deed zich voor in de regio, waarin Aken, Hasselt, Luik en Maastricht zijn gelegen. Ook hier een netwerk van vroeg industrialiserende steden met vanaf circa 1810 een hoofdrol voor Luik met zijn zware industrie, een plaats als subagglomeratie voor Aken met veel textiel en metaalverwerking, een minder geprononceerde rol voor Maastricht met vanaf 1832 glas en aardewerk en iets later papier en diverse Limburgs-Luikse grensdorpen met strohoedenfabricage. Vroegtijdige aanleg van spoorwegen maakte van de regio snel een een- 
heid op arbeidsmarktterrein. De grote aantallen grensarbeiderspassen, die de gouverneurs van Limburg tot 1914 uitreikten, leggen er getuigenis van af. De samenhang van de regio werd nog versterkt door de grote verschillen in hoofdelijk inkomen tussen Luik-Aken en de beide provincies Limburg, met als gevolg dat de markten en winkels in Maastricht overstroomd werden door Frans- en Duitstalige koopjesjagers, zozeer zelfs dat de Nederlandse gulden er werd verdreven ten gunste van de frank en de mark.

Arbeiders, neringdoenden en winkelpersoneel, ze dienden allemaal enig Duits en Frans te verstaan en te spreken. Maar nu kon de bovenlaag van de bevolking geen status meer ontlenen aan zijn kennis van het Frans. Er waren echter andere mogelijkheden om te laten zien dat men zich verheven voelde boven het gewone volk. Charitatieve werken en het propageren van burgerlijke waarden voldeden perfect aan dit verlangen, mits men de nodige contacten wist te leggen met het gewone volk. Daar was voor nodig dat men zich niet afkerig toonde van dialectgebruik. De Maastrichtse elite vond een voortreffelijke oplossing: ze verhief het lokale dialect tot de cultuurtaal van de lach. De 'kemikke opera' werd geboren en het volksfeest bij uitstek, het carnaval, benut om te laten zien en horen dat de volkstaal zich bij uitstek leende voor een rol als uitdrukkingsmiddel van de humor. Het kan zijn dat sociale factoren gaandeweg de rol van de domeinen overnamen.

Al slaagt mevrouw Kessels er niet helemaal in de uitkomsten van haar onderzoek sluitend te verklaren, de rijke documentatie die zij bijeenbracht over het sociaal-culturele leven in Nederlands meest zuidelijke stad en in zeer verzorgde taal weergaf, maakt van haar boek een lezenswaardig werk dat wetenschappelijke perspectieven opent.

J. C. G. M. Jansen

G. Wiersma, Mietje Hulshoff of De aanslag op Napoleon (Amsterdam: Bert Bakker, 2003, 175 blz., €17,95, ISBN 903512573 8).

Tijdgenoten zagen in haar een moderne Jaël of een Nederlandse Charlotte Corday. Zelf vergeleek zij zich het liefst met Jeanne d'Arc. Maar hoe moet Maria Hulshoff nu precies worden geduid: als een idealistische vrijheidsstrijdster, een gemankeerde tirannenmoordenares, 'een staatkundige dweepster' of het naïeve slachtoffer van politieke agitatoren? Uit het boekje dat Geertje Wiersma aan haar wijdde, wordt dit helaas niet duidelijk, zoals wel meer niet duidelijk wordt.

Maria Aletta Hulshoff (1781-1846) was de dochter van de vooruitstrevende, doopsgezinde predikant Allard Hulshoff, die zijn enthousiasme voor de politieke en maatschappelijke denkbeelden van de Verlichting op haar overdroeg. Als radicaal democrate raakte zij tijdens de opeenvolgende Bataafse regimes steeds meer teleurgesteld. De voortgaande beknotting van de vrijheid en de vergaande Franse inmenging in de binnenlandse politiek riepen haar weerzin en weerstand op. Bij herhaling werd Hulshoff in verband gebracht met de verspreiding van tegen de regering gerichte schotschriften. Leende zij in 1804 nog slechts haar naam aan een door anderen geschreven opruiend geschrift, van de Oproeping van het Bataafsche volk uit 1806 en van de Waarschouwing tegen de requisitie uit 1809 was zij wel de auteur. Ook het pamflet Droevige klagt van een aalmoeseniers-weeskind uit 1808 moet hoogstwaarschijnlijk aan haar worden toegeschreven. Dat beweert althans Johan Joor in zijn dissertatie De adelaar en het lam (2000), maar Wiersma zwijgt daarover.

Hulshoff verrichtte deze gezagsondermijnende activiteiten niet in het geheim. Integendeel, zij wilde niets liever dan dat de overheid haar hiervoor veroordeelde om op die manier haar 